\title{
PENGARUH PEMBERIAN SARI BATANG NANAS (ANANAS COMOSUS) TERHADAP TOTAL TROMBOSIT TIKUS WISTAR YANG DIBERI PAPARAN ASAP ROKOK
}

\author{
Roberta Lei Easter, Enny Probosari ${ }^{*}$ ) \\ Program Studi Ilmu Gizi Fakultas Kedokteran Universitas Diponegoro \\ J1.Dr.Sutomo No.18, Semarang, Telp (024) 8453708, Email : gizifk@ undip.ac.id
}

\begin{abstract}
ABSTRACK
Background: Cigarette smoking is a recognized risk factor for cardiovascular diseases and has been implicated in the pathogenesis of atherosclerosis. Platelet aggregation increase as a result of cigarette smoke exposure. It could lead to the higher risk of arterial thrombosis. Cigarette smoke could consequently make higher rate of cardiovascular events. Bromelain on pineapple stem juice works as antithrombotic that can reduce platelet aggregation caused by cigarette smoke exposure.

Method: Sixteen experimental and control male wistar rats were selected for the study. One control group and two experimental groups had exposed by 2 non-filtered cigarettes per group per day for 30 days. The two experimental groups administrated by pineapple stem juice containing bromelain 20mg/kg weight and $40 \mathrm{mg} / \mathrm{kg}$ weight, respectively. The total thrombocyte was determined.

Results: Increase total thrombocytes count after stem pineapple juice administration were observed in rats exposed by cigarette smoke. Total thrombocytes count were positively correlated with administration of stem pineapple juice $(p=0.044)$ in wistar rats exposed by cigarette smoke.

Conclusion: Administration of stem pineapple juice might have resulted in the increased of total thrombocytes count after cigarette smoke exposure in wistar rats.

Keywords: stem pineapple juice, bromelain enzyme, total thrombocyte, cigarette smoke exposure
\end{abstract}

\section{ABSTRAK}

Latar Belakang: Asap rokok merupakan salah satu faktor risiko terjadinya penyakit kardiovaskular dan berperan dalam patogenesis aterosklerosis. Agregasi platelet meningkat bersamaan dengan adanya paparan asap rokok. Peningkatan agregasi platelet tersebut dapat meningkatkan risiko arterial thrombi. Bromelain pada sari batang nanas merupakan zat antitrombotik yang dapat menurunkan tingkat agregasi platelet akibat paparan asap rokok.

Method: Enam belas tikus wistar dalam kelompok kontrol dan perlakuan digunakan dalam penelitian. Kelompok kontrol dan dua kelompok perlakuan dipapar 2 batang rokok per hari selama 30 hari. Dua kelompok perlakuan diberikan sari batang nanas yang mengandung bromelain masing-masing sebanyak 20mg/kgBB dan $40 \mathrm{mg} / \mathrm{kgBB}$. Total trombosit kemudian diukur pada akhir penelitian.

Results: Terdapat peningkatan total trombosit setelah pemberian sari batang nanas pada tikus yang terpapar asap rokok. Pemberian sari batang nanas berpengaruh terhadap total trombosit tikus wistar yang diberi paparan asap rokok $(p=0.044)$.

Conclusion: Pemberian sari batang nanas dapat meningkatkan total trombosit yang mengalami penurunan akibat paparan asap rokok.

Kata kunci: sari batang nanas, enzim bromelain, total trombosit, paparan asap rokok

\section{PENDAHULUAN}

Merokok merupakan salah satu gaya hidup yang amat mempengaruhi kesehatan manusia. Sekitar 900 juta orang atau sekitar $84 \%$ dari total perokok dunia tinggal di negara-negara berkembang, termasuk di Indonesia. Bahkan Indonesia berada pada urutan ketiga terbanyak dengan angka mencapai $146.860 .000 .{ }^{1}$ Kegiatan merokok tersebut tidak hanya berdampak buruk pada orang yang merokok namun juga pada orangorang yang berada di sekitarnya yang terpapar asap rokok. Second-hand smoker atau yang sering disebut perokok pasif juga turut terkena dampaknya. Pada tahun 2004, sebanyak $40 \%$ anakanak, 33\% laki-laki tidak merokok dan 35\% wanita tidak merokok terpapar asap rokok dari lingkungan sekitar. Paparan asap rokok tersebut setidaknya mengakibatkan 600.000 kematian per tahunnya di seluruh dunia. ${ }^{2,3}$ Selain itu secondhand smoke juga menyebabkan dan memperparah kondisi penyakit asma dan masalah pernafasan lainnya, khususnya pada anak anak. ${ }^{2,4,5}$

Asap rokok yang memiliki kandungan zat kimia lebih dari 2.500 komponen dapat menjadi zat tunggal yang berbahaya atau pun bereaksi dengan zat lain dan membentuk komponen baru. Kandungan utama dalam asap rokok yang berbahaya antara lain nikotin, karbon monoksida, tar dan cugenol pada rokok kretek. ${ }^{6,7}$ Pada orang yang terpapar asap rokok, dapat terjadi peningkatan

\footnotetext{
${ }^{*}$ Penulis Penanggungjawab
} 
konsentrasi nikotin dalam plasma sebesar $5 \mathrm{ng} / \mathrm{ml}$ hingga $24 \mathrm{ng} / \mathrm{ml}$ dan $<1 \mathrm{ng} / \mathrm{ml}^{8}{ }^{8}$ Peningkatan konsentrasi nikotin tersebut dapat memicu limpa untuk melepaskan trombosit dan meningkatkan aktivitas agregasi platelet sehingga jumlah trombosit dalam sirkulasi darah menurun. ${ }^{9-10}$ Perubahan jumlah trombosit dan aktivasi trombosit dalam darah disebabkan oleh adanya kondisi inflamasi akibat paparan asap rokok dan dapat meningkatkan risiko terjadinya penyakit kardiovaskular. ${ }^{11,12}$

Batang nanas (Ananas comoscus) belum banyak dieksplorasi di Indonesia sebagai salah satu herbal yang memiliki kemampuan untuk membantu meringankan suatu kondisi penyakit. Sebagian besar orang percaya pada kemampuan obat-obatan buatan pabrik dan mengesampingkan bantuan zat gizi yang terkandung di dalam bahan-bahan alami. Padahal mungkin saja obat-obatan herbal dapat memberikan kontribusi dalam penyembuhan penyakit. Salah satunya adalah batang nanas yang mengandung bromelain.

Bromelain merupakan gabungan enzim proteolitik yang diturunkan dari sari batang nanas. Bromelain dari batang nanas merupakan sumber protease terbesar yang ada dalam ekstraknya dibandingkan bromelain pada jus buah nanas itu sendiri. ${ }^{13}$ Bromelain dari batang nanas diakui sebagai agen terapeutik. Efek terapeutik pertama kali dikenalkan oleh Heinecke pada tahun 1957 sebagai pereda inflamasi akut dan kecelakaan pada olah raga. Selain itu juga banyak digunakan untuk berbagai penyakit dengan gangguan pernafasan seperti sinusitis dan bronkitis. ${ }^{14,15}$ Bromelain dalam dosis $20 \mathrm{mg} / \mathrm{kg}$ berat badan dan $40 \mathrm{mg} / \mathrm{kg}$ berat badan telah dibuktikan memiliki efek anti inflamasi. ${ }^{16}$

Seperti yang telah diuraikan sebelumnya, bromelain merupakan enzim anti-inflamasi, namun bromelain juga memiliki banyak kegunaan lain, salah satunya adalah antitrombotik dan antiagregasi platelet. ${ }^{17}$ Efek bromelain tersebut dapat membantu menekan tingginya agregasi platelet dan meningkatkan trombosit dalam sirkulasi darah yang menurun akibat paparan asap rokok. Selain itu, belum banyak penelitian di Indonesia yang mengulas mengenai efek bromelain dalam batang nanas sebagai antitrombotik dan antiagregasi platelet. Oleh karena itu peneliti ingin mengetahui pengaruh pemberian enzim bromelain dalam sari batang nanas terhadap total trombosit pada tikus wistar yang diberikan paparan asap rokok.

\section{METODE PENELITIAN}

Metode yang digunakan dalam penelitian ini adalah metode eksperimental dengan post-test only with randomized control group design. Sampel minimal yang disyaratkan untuk hewan coba berdasarkan WHO adalah 5 ekor di setiap kelompok dengan perhitungan antisipasi drop-out menjadi 6 ekor di setiap kelompok. Hewan coba yang digunakan adalah tikus galur wistar berjenis kelamin jantan dengan usia 6 minggu. Pemilihan jenis kelamin jantan untuk hewan coba bertujuan mengurangi bias akan adanya perubahan hormon yang dapat lebih besar terjadi pada tikus berjenis kelamin betina yang dapat mempengaruhi proses intervensi pada hewan coba. Tikus wistar jantan yang berusia 6 minggu merupakan usia dewasa awal di mana tikus wistar jantan diharapkan dalam kondisi optimal dalam hal kemampuan regenerasi sel. Kisaran berat tikus wistar jantan usia 6 minggu adalah 150 gram - 200 gram.

Variabel bebas (independent variable) pada penelitian ini adalah pemberian sari batang nanas yang diberikan pada dua tingkat dosis yaitu 20 $\mathrm{mg} / \mathrm{kgBB} / \mathrm{hari}$ dan $40 \mathrm{mg} / \mathrm{kgBB} / \mathrm{hari}$. Variabel terikat (dependent variable) adalah total trombosit tikus wistar. Variabel terkontrol (control variable) adalah galur tikus, jenis kelamin tikus, pakan, sistim perkandangan hewan coba, dan pemaparan asap rokok. Pemaparan asap rokok dilakukan setiap hari dengan cara memasukkan tikus dalam kotak berukuran $30 \mathrm{~cm} \times 40 \mathrm{~cm} \times 50 \mathrm{~cm}$ dengan ukuran ventilasi $5.6 \mathrm{~cm} \times 28.4 \mathrm{~cm}$ (Lampiran 1). Rokok yang dibakar adalah jenis rokok kretek non filter dengan kandungan tar $2.4 \mathrm{mg}$ dan nikotin $38 \mathrm{mg}$ per batang. Pengasapan dilakukan selama 30 menit sebanyak 2 batang/hari/per kelompok.

Batang nanas (Ananas comosus) yang digunakan berasal dari varietas Cayenne berusia 2 tahun dan didapatkan dari petani nanas di Wonosari. Batang nanas merupakan bagian nanas yang berada di bawah tanah hingga pangkal daun. Batang nanas yang telah dibersihkan kemudian dipotong-potong menjadi bagian yang lebih kecil. Setelah itu potongan batang nanas dihaluskan dengan juicer tanpa tambahan air lalu disaring untuk mengurangi ampas. Sari batang nanas disimpan dalam suhu rendah di lemari pendingin untuk mencegah kerusakan enzim bromelain. Berdasarkan penelitian Anannya, dinyatakan terdapat $0,95 \mathrm{mg}$ enzim bromelain dalam $0,1 \mathrm{ml}$ sari batang nanas. ${ }^{18}$

Sebanyak delapan belas tikus dibagi menjadi 3 kelompok secara acak, yaitu kelompok kontrol, kelompok perlakuan 1 dan kelompok perlakuan 2. Ketiga kelompok mendapatkan kondisi pengasapan yang sama. Perbedaan terdapat pada 
intervensi setelah pemaparan asap rokok. Pada kelompok kontrol tidak diberikan sari batang nanas setelah pengasapan, kelompok perlakuan 1 diberikan sari batang nanas sebanyak $3,1 \mathrm{ml} / \mathrm{hari}$ $(20 \mathrm{mg} / \mathrm{kgBB} / \mathrm{hari})$ dan kelompok perlakuan 2 diberikan sari batang nanas sebanyak $6,2 \mathrm{ml} / \mathrm{hari}$ (40 mg/kgBB/hari) dengan metode sonde (Lampiran 2). Pemberian sari batang nanas dibagi menjadi dua kali dengan pertimbangan jumlah maksimal lambung tikus $\pm 5 \mathrm{cc}$. Pemberian sari batang nanas pertama dilakukan satu jam setelah pemaparan asap rokok. Pemberian pertama sebanyak $1,5 \mathrm{ml}$ per tikus untuk kelompok perlakuan 1 dan $3,1 \mathrm{ml}$ per tikus untuk kelompok perlakuan 2. Pemberian sari batang nanas kedua berjarak 1 jam setelah pemberian pertama dengan dosis $1,6 \mathrm{ml}$ per tikus untuk kelompok perlakuan 1 dan 3,1 ml per tikus untuk kelompok perlakuan 2.

Pemeliharaan hewan coba dilakukan di Laboratorium Fisiologi Hewan Jurusan Biologi Fakultas MIPA Universitas Negeri Semarang dan pengujian sampel darah dilakukan di Balai Laboratorium Kesehatan Provinsi Jawa Tengah. Pengambilan sampel trombosit dilakukan pada hari ke-31 melalui plexus retro orbitalis sebanyak $\pm 1 \mathrm{cc}$ setelah berpuasa selama 12 jam (Lampiran 3). Total trombosit dianalisis dengan menggunakan alat blood analyzer Mikros 6.0.
Pengolahan data dilakukan dengan program komputer. Uji normalitas data menggunakan uji Saphiro-Wilk. Dilanjutkan dengan uji statistik parametrik menggunakan one way ANOVA dan Post Hoc LSD (Lampiran 4). Seluruh pelaksanaan penelitian ini telah memperoleh persetujuan dari Komite Etik Penelitian Kesehatan Fakultas Kedokteran Universitas Diponegoro.

\section{HASIL PENELITIAN}

Pada penelitian yang berlangsung selama 30 hari, tiga ekor tikus mengalami dropout. Dua ekor pada kelompok kontrol dan satu ekor pada kelompok perlakuan 2. Dilakukan penggantian satu ekor tikus pada kelompok kontrol untuk memenuhi syarat jumlah sampel hewan coba WHO pada satu kelompok. Sehingga jumlah akhir sampel pada tiap kelompok yaitu 5 ekor pada kelompok kontrol, 6 ekor pada kelompok perlakuan 1, dan 5 ekor pada kelompok perlakuan 2. Pada hari ke-31 dilakukan pengambilan dan pengujian sampel darah untuk mengetahui total trombosit setelah intervensi (lampiran 5). Hasil uji normalitas menunjukkan bahwa data berdistribusi normal (kontrol $\mathrm{p}=0.928$, perlakuan $1 \mathrm{p}=0.348$, perlakuan $2 \mathrm{p}=0.858$ ) dan homogen $(p=0,240)$. Karena semua data berdistribusi normal dan homogen, analisis data dilanjutkan dengan uji statistik parametrik one way Anova dengan hasil berikut:

Tabel 1. Rerata total trombosit dan pengaruh pemberian sari batang nanas antarkelompok

\begin{tabular}{lllcc}
\hline & Kelompok & n & Rerata \pm SD & $p$ \\
\hline \multirow{3}{*}{ Total trombosit } & Kontrol & 5 & $6.70 \mathrm{E} 5 \pm 131837.78$ & \\
& Perlakuan 1 & 6 & $7.85 \mathrm{E} 5 \pm 270342.75$ & 0.044 \\
& Perlakuan 2 & 5 & $1.05 \mathrm{E} 6 \pm 217371.11$ & \\
\hline
\end{tabular}

1. Hasil uji One-Way ANOVA

Hasil analisis one way ANOVA didapatkan $p=0.044$. Berdasarkan data tersebut maka dapat disimpulkan bahwa Ho ditolak atau terdapat pengaruh pemberian sari batang nanas terhadap total trombosit. Data rata-rata pada perlakuan 2 merupakan yang paling tinggi $(1.05 \mathrm{E} 6 \pm 217371.11 / \mu \mathrm{L})$ dibandingkan dengan kelompok kontrol $(6.70 \mathrm{E} 5 \pm 131837.78 / \mu \mathrm{L})$ dan kelompok perlakuan $1(7.85 \mathrm{E} 5 \pm 270342.75 / \mu \mathrm{L})$. Uji post-hoc Least Significant Different (LSD) kemudian dilakukan untuk mengetahui adanya perbedaan antarkelompok (antara kelompok kontrol positif, kelompok perlakuan 1, dan kelompok perlakuan 2).

Tabel 2. Perbedaan pengaruh sari batang nanas pada masing-masing kelompok

\begin{tabular}{|c|c|c|c|c|}
\hline & \multirow{2}{*}{ Perbedaan rerata } & \multicolumn{2}{|c|}{ IK 95\% } & \multirow[b]{2}{*}{$p$} \\
\hline & & Minimum & Maksimum & \\
\hline $\begin{array}{l}\text { Kontrol dan } \\
\text { perlakuan } 1\end{array}$ & 114800.00 & -19794.17 & 680937.85 & 0.403 \\
\hline $\begin{array}{l}\text { Kontrol dan } \\
\text { perlakuan } 2\end{array}$ & 381600.00 & -553394.17 & 401394.17 & 0.016 \\
\hline $\begin{array}{l}\text { Perlakuan } 1 \text { dan } \\
\text { perlakuan } 2\end{array}$ & 266800.00 & -680937.85 & 171794.17 & 0.066 \\
\hline
\end{tabular}

1. Hasil uji post-hoc LSD

Hasil dari uji post-hoc diketahui bahwa $p=0.403$, kelompok kontrol dan perlakuan 2 rerata antara kelompok kontrol dan perlakuan 1 nilai $\quad p=0.016$, kelompok perlakuan 1 dan perlakuan 2 
$p=0.066$. Berdasarkan nilai $p$ dapat disimpulkan terdapat perbedaan rata-rata total trombosit kelompok kontrol dan kelompok perlakuan 2, namun tidak ada perbedaan yang bermakna antarkelompok kontrol dengan perlakuan 1 dan kelompok perlakuan 1 dengan kelompok perlakuan 2 .

\section{PEMBAHASAN}

Ketiga kelompok diberikan paparan asap rokok 2 batang/hari selama 30 menit. Paparan asap rokok sebanyak 2 batang/hari digolongkan sebagai intensitas paparan dosis rendah, sedangkan yang tergolong sebagai intensitas paparan dosis tinggi yaitu sebanyak 20 batang/hari. ${ }^{19}$ Pemaparan asap rokok dalam kondisi tersebut selama 30 hari dapat menimbulkan stress oksidatif melalui mekanisme peningkatan radikal bebas dalam darah. ${ }^{20}$ Untuk menekan reaksi inflamasi dan terjadinya agregasi platelet, diberikan bromelain dari sari batang nanas sebanyak $20 \mathrm{mg} / \mathrm{kgBB} / \mathrm{hari}$ untuk kelompok perlakuan 1 dan 40mg/kgBB/hari untuk kelompok perlakuan 2; dimana diasumsikan pada $0,1 \mathrm{ml}$ mengandung $0.95 \mathrm{mg}$ bromelain. ${ }^{18}$ Berdasarkan data yang diperoleh, diketahui bahwa rerata total trombosit pada kelompok kontrol lebih rendah $(670.200 / \mu \mathrm{L})$ dibandingkan total trombosit pada kelompok perlakuan $1(785.000 / \mu \mathrm{L})$ dan kelompok perlakuan $2(1.051 .800 / \mu \mathrm{L})$. Berdasarkan data tersebut dapat dilihat bahwa telah terjadi peningkatan rerata total trombosit pada kelompok perlakuan 1 dan kelompok perlakuan 2 dibandingkan kelompok kontrol. Data tersebut menunjukkan efek pemberian sari batang nanas terhadap total trombosit yang didukung dengan hasil uji one-way ANOVA dengan adanya pengaruh perlakuan sebesar $p=0.044$.

Agregasi platelet yang terjadi akibat paparan asap rokok menurunkan jumlah trombosit dalam sirkulasi darah. Kadar nikotin plasma yang meningkat akibat paparan asap rokok akan memicu syaraf simpatis akan adanya kondisi inflamasi. Mekanisme respon inflamasi akan teraktivasi dengan meningkatkan kadar sitokin dan IL-6. Peningkatan tersebut akan memicu produksi trombopoetin (TPO) di hepar yang akan memicu trombopoesis. ${ }^{21}$ Meskipun trombopoesis terus berlangsung, jumlah trombosit dalam sirkulasi darah tetap menurun akibat meningkatnya agregasi platelet, dipicu oleh nikotin yang merusak lapisan endhotelial dan mengaktifkan respon inflamasi. ${ }^{22}$

Seperti yang telah disebutkan sebelumnya, kelompok perlakuan 2 menunjukkan angka kenaikan total trombosit lebih besar dibandingkan angka kenaikan pada kelompok perlakuan 1 jika disandingkan dengan kelompok kontrol. Angkaangka tersebut menunjukkan pengaruh kinerja bromelain pada setiap kelompok. Dapat dilihat bahwa rerata total trombosit pada kelompok kontrol merupakan yang paling rendah dibandingkan kelompok perlakuan lain. Hal tersebut menunjukkan terjadinya agregasi platelet yang lebih tinggi pada kelompok kontrol. Adanya agregasi platelet akan menurunkan total trombosit dalam sirkulasi darah. Pemberian bromelain dengan dosis yang bertingkat pada masing-masing kelompok perlakuan memberikan perbedaan yang cukup signifikan pada rerata total trombosit yang dihasilkan. Rerata total trombosit pada kelompok perlakuan 1 dan kelompok perlakuan 2 memiliki perbedaan yang cukup banyak, yaitu yaitu sekitar $350 \times 10^{3} \mathrm{sel} / \mathrm{mm}^{3}$, meskipun tidak sebesar perbedaan yang terdapat antara kelompok kontrol dengan kelompok perlakuan 2, yaitu sebesar $380 \mathrm{x}$ $10^{3} \mathrm{sel} / \mathrm{mm} 3$. Hasil tersebut menunjukkan adanya pengaruh dosis bromelain yang diberikan terhadap rerata total trombosit. Angka tersebut membuktikan bahwa bromelain dapat membantu menekan aktivitas agregasi platelet dengan menghambat pembentukan thrombin sehingga menaikkan total trombosit dalam sirkulasi darah. ${ }^{23}$

Meskipun rerata total trombosit menunjukkan adanya kenaikan yang signifikan, terdapat beberapa penurunan total trombosit yang tidak sesuai dengan teori. Pada kelompok perlakuan 1, tidak semua sampel memiliki angka yang lebih tinggi dibandingkan kelompok kontrol. Begitu juga pada kelompok perlakuan 2 yang tidak seluruh sampelnya memiliki angka yang lebih tinggi dibandingkan kelompok perlakuan 1 . Grafik berikut menggambarkan pola kenaikan dan penurunan total trombosit pada setiap kelompok: 


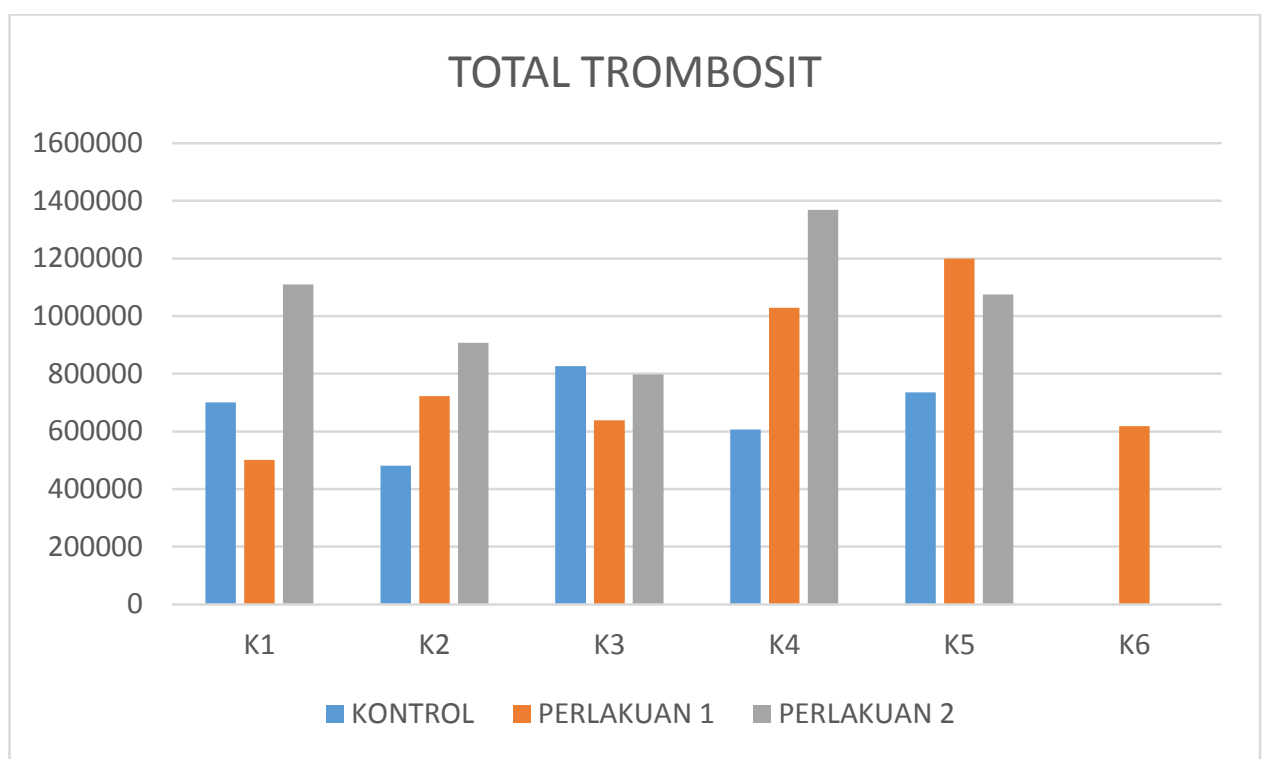

Grafik 1. Pola kenaikan dan penurunan total trombosit pada setiap kelompok

Penelitan yang dilakukan oleh Metzig et al membandingkan efektifitas bromelain dalam menurunkan agregasi platelet pada berbagai dosis. Metzig et al menyatakan bahwa dosis $30 \mathrm{mg} / \mathrm{kgBB}$ yang diberikan melalui intravena merupakan dosis dan jalur yang paling efektif, bahkan dibandingkan dengan enzim papain dan trypsin. ${ }^{23}$ Penelitian ini memberikan dosis $20 \mathrm{mg} / \mathrm{kgBB}$ dan $40 \mathrm{mg} / \mathrm{kgBB}$ melalui oral sebagai dosis efektif anti-inflamasi umum, seperti yang dinyatakan oleh Sri Agus Sudjarwo pada penelitiannya. ${ }^{16}$ Beberapa sampel yang menunjukkan data yang tidak sesuai teori mungkin disebabkan oleh tingkat dosis optimal pada setiap tikus yang berbeda-beda, sehingga terdapat perbedaan respon tubuh. Sebuah penelitian menyatakan bahwa pemberian bromelain pada tikus wistar melalui intravena mencapai dosis optimal pada $30 \mathrm{mg} / \mathrm{kgBB} .{ }^{23}$ Pernyataan tersebut mungkin dapat menjadi salah satu penyebab adanya ketidak sesuaian hasil intervensi. Kondisi ini juga ditunjukkan oleh hasil uji post-hoc LSD yang menunjukkan tidak adanya perbedaan nilai yang bermakna antara kelompok perlakuan 1 dengan kelompok perlakuan $2(p=0.066)$ dan antara kelompok perlakuan kontrol dengan kelompok perlakuan $1(p=0.403)$. Berdasarkan hasil uji posthoc LSD, hanya kelompok kontrol dan kelompok perlakuan 2 yang memiliki perbedaan nilai yang bermakna $(p=0.016)$

Sari batang nanas yang diberikan tidak melalui uji pendahuluan terlebih dahulu sehingga tidak diketahui secara pasti besar kandungan yang terdapat dalam satu mililiter sari batang nanas. Perhitungan kandungan dilakukan berdasarkan literatur dengan menyesuaikan umur tanaman dan varietas yang sama dengan literatur. Kandungan enzim bromelain dalam satu mililiter sari batang nanas yang diberikan mungkin lebih rendah atau lebih tinggi dibandingkan dosis optimal.

\section{SIMPULAN}

Terdapat pengaruh pemberian sari batang nanas terhadap total trombosit tikus wistar yang diberi paparan asap rokok $(p=0.044)$. Terdapat perbedaan nilai yang bermakna antara kelompok kontrol dengan kelompok perlakuan $2(p=0.016)$ sedangkan tidak terdapat perbedaan nilai yang bermakna antara kelompok kontrol dengan kelompok perlakuan $1(p=0.403)$ dan antara kedua kelompok perlakuan $(p=0.066)$.

\section{DAFTAR PUSTAKA}

1. World Health Organization. World health statisitics 2011. World Health Stat 2011. 2011:12.

2. World Health Statistic. WHO Report on the Global Tobacco Epidemic 2009: Implementing SmokeFree Environments. Geneva; 2011.

3. World Health Organization. Global Health Observatory (GHO) data. Second-Hand Smoke.; 2015:8-9.

4. Tobacco Free Initiative (TFI).; World Health Organization. 2015: 1-3.

5. Global Tobacco Control. John Hopkins Bloomberg School of Public. Atlanta; 2014: 21.

6. Murdiyati, Tirtosastro. Kandungan Kimia Tembakau dan Rokok. Tanam Tembakau, Serat dan Miny Ind. 2010;2(1):33-43.

7. I M. Efek Antioksidan Vitamin C Terhadap Tikus (Rattus novegicus L) Jantan Akibat Pemaparan Asap Rokok. dissertation. 2009.

8. Zevin, Saunders, Goulray, Peyton, Benowitz. Cardiovascular effects of carbon monoxide and cigarette smoking. J Am Coll Cardiol. 2001;38:1633-1638. 
9. Mundal HH, Hjemdahl P, Gjesdal K. Acute effects of low dose nicotine gum on platelet function in non-smoking hypertensive and normotensive men. Eur J Clin Pharmacol. 1995;47:411-416.

10. MUNDAL H, HJEMDAHL P, GJESDAL K. Acute Effects of Cigarette Smoking on Platelet Function and Plasma Catecholamines in Hypertensive and Normotensive Men. Am J Hypertens. 1998;11(6):677-681. doi:10.1016/S08957061(98)00022-3.

11. Jackson SP. The growing complexity of platelet aggregation Review article The growing complexity of platelet aggregation. Blood. 2006;109(12):5087-5095. doi:10.1182/bloodHistorical.

12. Huber GL, Brockie RE. Passive smoking and heart disease. Circulation. 1991;84(4):1878-1879. doi:10.1161/01.CIR.84.4.1878.

13. Looze Y. Stem Bromelain. 1993:1871-1873. doi:10.1016/B978-0-12-382219-2.00423-3.

14. Bala M, Ismail NA, Mel M, et al. Bromelain Production : Current Trends and Perspective. Arch Des $\quad$ Sci. 2012;65(11):369-399. http://irep.iium.edu.my/28364/1/Bromelain_review .pdf.

15. Bhattacharyya BK. Bromelain: an overview. Nat Prod Radiance. 2008;7(4):359-363. email: calbarun@yahoo.com\nhttp://www.niscair.res.in \n http://micro189.lib3.hawaii.edu:2048/login?url=htt p://search.ebscohost.com/login.aspx?direct=true\& $\mathrm{db}=$ lah\&AN=20083295107\&site=ehost-live.

16. Sudjarwo SA. Anti-inflammatory and analgesic effect of bromelain. 2005;24(4):155-160.

17. US Patent. Application F, Data P. 4,507,286. 1985.
18. Mohapatra A, Rao VM, Ranjan M. Comparative study of the increased production \& characterization of Bromelain from the peel, pulp \& stem pineapple (Anannus commas). 2013;2(8):249279.

19. D'hulst a I, Vermaelen KY, Brusselle GG, Joos GF, Pauwels $\mathrm{R}$ a. Time course of cigarette smokeinduced pulmonary inflammation in mice. Eur Respir J Off J Eur Soc Clin Respir Physiol. 2005;26(2):204-213. doi:10.1183/09031936.05.00095204.

20. Ambrose JA, Barua RS. The pathophysiology of cigarette smoking and cardiovascular disease dan tobacco smoke carcinogens, DNA damage and p53 mutations in smoking-associated cancers. J Am Coll Cardiol. 2004;43(7):1731.

21. Erickson - Miller CL, Ji H, Murphy MJ. Megakaryocytopoiesis and platelet production: does stem cell factor play a role? Stem Cells. 1993;11(2):163-169.

22. Nowak J, Murray JJ, Oates J a, FitzGerald G a. Biochemical evidence of a chronic abnormality in platelet and vascular function in healthy individuals who smoke cigarettes. Circulation. 1987;76(1):614. doi:10.1161/01.CIR.76.1.6.

23. Metzig C, Grabowska E, Eckert K, Rehse K, Maurer HR. Bromelain proteases reduce human platelet aggregation in vitro, adhesion to bovine endothelial cells and thrombus formation in rat vessels in Vivo. In Vivo (Brooklyn). 1999;13(1):712. 